\title{
Socio Economic Contribution of Lowland Bamboo (Oxythenanthera Abyssinica) in Pawe District, Ethiopia
}

\author{
Zeleke Melese \\ Ethiopia agricultural research institute Pawe agricultural research center
}

\begin{abstract}
The Study was conducted in Pawe district, Benishangul-Gumuz National Regional State, northwestern Ethiopia. The objective of this study was to evaluate socio-economic aspects of low land bamboo (Oxythenanthera abyssinica). For this study, two villages were selected based on random sampling technique., Data were collected from a total of 136 households. Households were selected using simple random sampling technique. The collected raw data were systematically coded and analyzed using descriptive statistics. A weighed direct matrix likert scale ranking of species was used to evaluate low land bamboo and others tree species based on multipurpose value. Inferential statistical, linear regression model was employed to find out the relationship between incomes generated from Low Land Bamboo and some selected socioeconomic factors (independent variables). The study result indicated that Out of the sampled households, $50 \%$ and $37.5 \%$ of the respondents ranked Mangifera indica and Lowland bamboo (Oxythenanthera abyssinica) first and second, respectively while Melia azedirachta L. and Cordia africana were preferred third $(8.1 \%)$ and fourth $(2.9 \%)$, respectively. Among the socio-economic characteristics considered land holding size was positively and highly significantly related to income generated by households $(\mathrm{p}<0.01)$. Therefore, the policies and strategies that improve the welfare of rural people especially the poor and the land less HHs and use of bamboo for natural resource conservation should be given attention. Additionally, government and NGOs should support and encourage cultivation of lowland bamboo and lowland bamboo based activities as part of the diversified livelihood strategies.
\end{abstract}

Keywords: Low Land Bamboo, socio economics, income.

DOI: $10.7176 / \mathrm{JNSR} / 10-9-03$

Publication date:May $31^{\text {st }} 2020$

\section{INTRODUCTION}

\subsection{Background and Justification}

Bamboo is the strongest and fastest growing perennial grass species that belongs taxonomically to the subfamily of Bambusoideae under the family of Gramineae (FAO, 2007). More than 1,500 species and 90 genera of bamboo are found in the world, covering 36 million ha of land which is distributed in the tropical and sub-tropical belt between $46^{0}$ north and $47^{0}$ south latitude at elevations as high as $4000 \mathrm{~m}$ above sea level (FAO, 2007) $)^{3}$. Regarding their abundances $65 \%, 28 \%$ and $7 \%$ of the world bamboo are found in Asia, America and Africa, respectively $(\mathrm{FAO}, 2007)^{3}$. Forty-three species and eleven genera of bamboo are found in Africa, with area coverage of 2.7 million ha. About $93 \%$ of Africa bamboo species are found only in Madagascar (FAO, 2007; Tesfaye Hunde, 2007; Seyoum Kelemwork, 2008) ${ }^{3,13,11}$. In terms of area coverage, $67 \%$ of the African and more than $7 \%$ of the world bamboo resource is found in Ethiopia (Ensermu et al., 2000; Kassahun Embaye, 2003; Seyoum Kelemwork, $2008)^{2,5,11}$. Ethiopia has two bamboo species namely, the high land bamboo,Yushaina alpina and the low land bamboo Oxytenanthera abyssinica). Out of which the high land bamboo comprises about 130,000 ha and low land bamboo covers over 850,000 ha (Ensermu et al., 2000; Kassahun Embaye, 2003) ${ }^{2,5}$.

Bamboo is a versatile and multifaceted non-timber plant with a considerable potential to the socio-economic development and environmental protection (Kumar and sastry, 1999) ${ }^{7}$. It has numerous benefits in day to day uses for the local community where the species is growing (Tesfaye Hunde, 1998) ${ }^{12}$. Due to their easy workability, strength, straightness, lightness, combined with extra-ordinary hardness, range of size, abundance, short period in which they attain maturity, make them suitable for a various of purpose and use (Nath et al., 2009 and kasahun Embaye, 2000) $)^{10,6}$. As result, there are more than 1,500 uses, ranging from medicine to nutrition and from toys to aircraft (Nath et al., 2009) $)^{10}$.

The primary use of raw bamboo material is for housing, fencing, household equipments and amenities. The majority of rural families are entirely dependent on raw bamboo for household furniture and as a source of domestic energy and Bamboo is the main material for the construction of house, animal sheds fences, fuel wood and beehives in Asossa Zone, Benshangul-Gumuz Region. In addition, for Jeblawi people of Mandura district in this Region, the shoots of bamboo are very important for their delicious nutritional food sources (LUSO Consult,

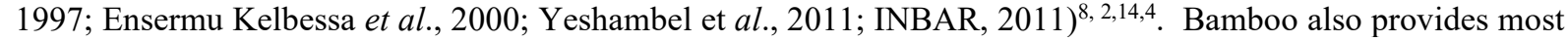
of the fodder for the livestock in the area of Awi and Metekel Zones (Yeshambel Mekuriaw et al., 2011) .

Bamboo Plays a vital role in environmental amelioration, biodiversity preservation, soil conservation and protects other plants from frost, wind and water erosion and itself from freely moving speedy winds and frost (Kassahun Embaye, 2003; ECOMAR Consult, 2011) ${ }^{5,1}$. It also contributes to flood management, wastage disposal, 
waste purification and ecological sanitation as well as recharging groundwater. Bamboo sequesters up to 12 tons of carbon dioxide from the air per hectare and it release $35 \%$ more oxygen than equivalent stands of trees $\left(\right.$ ECOMAR consultant, 2011) ${ }^{1}$. Despite the large area coverage, economic, social and conservation significance of bamboo in Ethiopia, information about production, utilization and its use as forage for livestock is limited (Yeshambel Mekuriaw et al., 2011) ${ }^{14}$. Therefore, the present study was conducted with the objectives of generating holistic information about regeneration status and socio-economic aspects of the indigenous low land bamboo species.

\section{The study was intended to achieve the following Objectives}

$>$ To evaluate farmers' preference of low land bamboo species and others tree species based on multipurpose value.

$>$ To evaluate the Relationship between household incomes from annual low land bamboo and socioeconomic characteristics.

\section{MATERIALS AND METHODS}

\subsection{Description of Study Area}

The study was conducted in Pawe district, Metekel Zone, Benishangul Gumuz National Regional State, North Westen Ethiopia at a distance of $560 \mathrm{~km}$ from Addis Ababa. The town of the pawe district is Addis Alem town. The town was established as resettlement area by the military government of Ethiopia in the year of $1984-1986$. The study villages were village 30 and village 23/45. And they are located 3 and $6 \mathrm{~km}$ from the town, respectively. The district lies between $36^{\circ} 15^{\prime} \mathrm{E}-36^{\circ} 34^{\prime} \mathrm{E}$ longitude and $11^{\circ} 10^{\prime} \mathrm{N}-11^{\circ} 23^{\prime} \mathrm{N}$ latitude. The elevation of the Woreda ranges from 980 to 1200 meter above sea level.

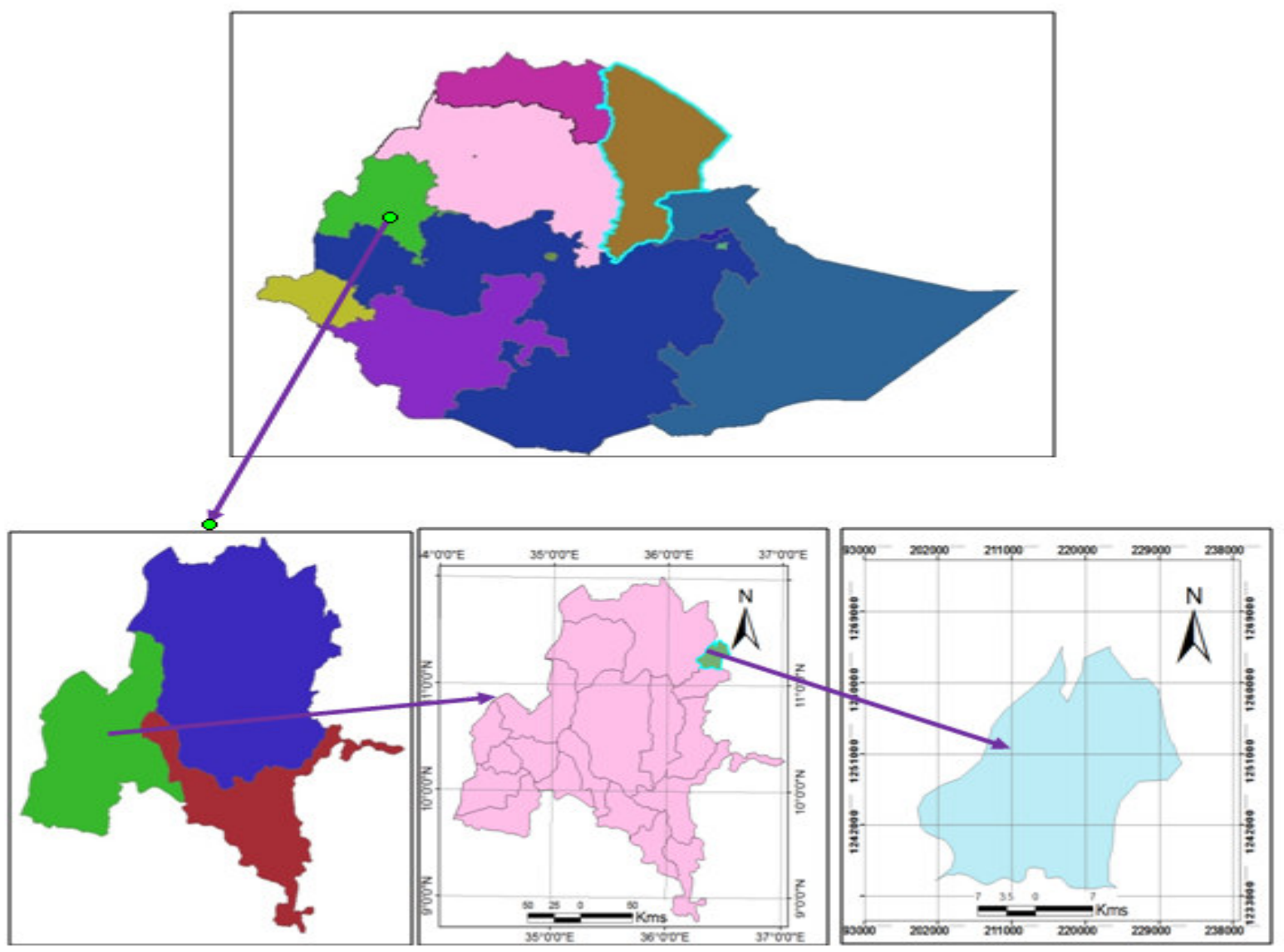

Figure 2. 1. Map of the study area

\subsection{Data Collection Methods and Sampling}

\subsubsection{Sampling method and procedure}

Selection of the study area, respondents and sampling technique has been conducted in the following procedure. Two villages namely village $23 / 45$ and village 30 were selected for the purposes of data collection because all villages in the district have the same potential for bamboo production. There are 8,562 total households in the two study village's 4,293 and 4,269 in village 23/45 and 30, respectively. 
From a list of households' heads available in the respective village, 68 sample households from each of the villages were selected. A total of 136 household heads were selected following Cochran (1977).

$$
n o=\frac{z^{2} p q}{d^{2}} \rightarrow n=\frac{n o}{1+\frac{n o-1}{N}}
$$

Where: no $=$ the desired sample size, if population is more than 10,000

$\mathrm{n}=$ number of sample size, if population is less than 10,000

$\mathrm{z}=95 \%$ confident limit i.e. 1.96

$\mathrm{p}=$ proportion population to be included in the sample i.e. $10 \%$

$\mathrm{q}=1-0.1$

$\mathrm{N}=$ total number of population

$\mathrm{d}=$ margin of error $(5 \%)$

Data was collected using questionnaires and supplemented by information obtained from making field checks at the time of survey and secondary data derived mainly from Office of Agriculture. Group discussions were held during the survey with key informants consisting of local community and local administrators. During the group discussion, information was gathered on issues related to the current socio economic contribution, and farmers' indigenous knowledge about the production and utilization of bamboo, and constraints that affect bamboo cultivation. In the discussion process, an individual issue was raised by the researcher.

\subsubsection{Socio economic data analysis}

In ranking the importance of bamboo, the number of respondents who reported for each rank were summed up and taken as the proportion from the total interviewed farmers for each kebele. The collected raw data were systematically coded and analyzed using descriptive statistics like mean using Statistical Package for Social Sciences (SPSS). A weighed direct matrix likert scale ranking of species was used to evaluate low land bamboo and others tree species based on multipurpose value. Here, refers to evaluation that was recorded on a scale from negative impact to extremely important. The categories used were given numerical labels as $0,1,2,3$ and 4 . Over all respondents ranking based on their own criteria (cash income, house construction, fuel wood, charcoal, animal fodder, agricultural tools and furniture) showed that farmers preferred the species in terms of multipurpose function. The collected data was summarized and present in the form of table, chart and figure form.

Inferential statistical tools especially the linear regression model (Larinde and Olasupo, 2011) was employed to find out the relationship between incomes generated from LLB and some selected socioeconomic factors

(independent variables).

$$
Y=\alpha+\beta_{1} X_{1}+\beta_{2} X_{2}+\beta_{2} X_{3}+\beta_{2} X_{4} \ldots \ldots \ldots \ldots
$$

Where $\mathrm{Y}=$ Income generated from LLB by the respondent

$\mathrm{X} 1=$ Age of household

$\mathrm{X} 2$ = Family size

$\mathrm{X} 3=$ Level of education

$\mathrm{X} 4=$ Land size of $\mathrm{HHs}$

Information was collected on each source of income of the households and each respondent were required to give an estimate of how much was produced, consumed and sold from each bamboo source of income. This basically depends on household's estimation of the amounts harvested consumed and sold rather than actually measured by researchers. Cash income was recorded on the basis of information obtained from the respondent households.

\section{RESULTS AND DISCUSSION}

\subsection{Analysis of socio-economic aspects of lowland bamboo (Oxythenanthera abyssinica) 3.1.1 Farmers' preference of bamboo species}

In study area about five tree species are dominantly used for household use to fulfill basic needs (Table 3.1). Out of the sampled households, $50 \%$ and $37.5 \%$ of the respondents ranked Mangifera indica and Lowland bamboo (Oxythenanthera abyssinica) first and second, respectively while Melia azedirachta L. and Cordia africana were preferred third $(8.1 \%)$ and fourth $(2.9 \%)$, respectively (Table 3.1. ). The majority of the respondent's ranked bamboo second next to Mangifera indica from any other trees (Table 3.1.). In terms economic perspectives, farmers prefer Mangifera indica due to market demand for it. While lowland bamboo is highly useful for domestic use for different uses, it has not the market access. As a result, farmers gave low attention to lowland bamboo than Mangifera indica.

In the study area, bamboo tree products are used for domestic use. As the respondents said that, now they use the bamboo products for construction of house, farm equipments and animal fodder. But before decades of years, all necessary products of forests were extracted from bamboo culms. But now accessibility of natural forest is limited, the use of bamboo culm is limited. This is in lined with Yeshambel Mekuriaw et al., (2010), The majority of the respondents (85\%) in Mandura and $73 \%$ in Pawe districts possess bamboo as a communal property (natural bamboo forest) The land allotted to private bamboo plantation in the lowland districts is small compared to the highland bamboo. Ensermu et al..( 2000) found no private plantation of lowland bamboo. However, plantation of 
lowland bamboo as private holding in backyard is currently an emerging activity. This could be attributed to the fact that access to lowland bamboo in natural forest is restricted as a result of reduction in area coverage.

Table 3. 1. Farmers' perception and preferences lowland bamboo and other trees

\begin{tabular}{|c|c|c|c|c|c|c|c|}
\hline \multirow[t]{2}{*}{ Site } & \multicolumn{6}{|c|}{ Household Participated in Pair-wise ranking } & \multirow[t]{2}{*}{ Rank } \\
\hline & choice & $\mathrm{EC}$ & MI & $\mathrm{CA}$ & $\mathrm{OA}$ & MA & \\
\hline & 1 & 2 & 32 & 2 & 27 & 5 & $1^{\text {st }}(\mathrm{MI})$ \\
\hline \multirow[t]{5}{*}{$23 / 45$} & 2 & 5 & 11 & 10 & 24 & 18 & $2^{\text {nd }}(\mathrm{OA})$ \\
\hline & 3 & 11 & 7 & 16 & 4 & 30 & $3^{\text {rd }}(\mathrm{MA})$ \\
\hline & 4 & 9 & 13 & 40 & 4 & 4 & $4^{\text {th }}(\mathrm{CA})$ \\
\hline & 5 & 41 & 5 & 0 & 9 & 11 & $5^{\text {th }}(\mathrm{EC})$ \\
\hline & 1 & 0 & 36 & 2 & 24 & 6 & $1^{\mathrm{st}}(\mathrm{MI})$ \\
\hline \multirow[t]{5}{*}{30} & 2 & 5 & 9 & 6 & 26 & 22 & $2^{\text {nd }}(\mathrm{OA})$ \\
\hline & 3 & 10 & 4 & 20 & 11 & 23 & $3^{\text {rd }}(\mathrm{MA})$ \\
\hline & 4 & 9 & 7 & 36 & 4 & 10 & $4^{\text {th }}(\mathrm{CA})$ \\
\hline & 5 & 44 & 12 & 4 & 3 & 7 & $5^{\text {th }}(\mathrm{EC})$ \\
\hline & 1 & 2 & 68 & 4 & 51 & 11 & $1^{\mathrm{st}}(\mathrm{MI})$ \\
\hline \multirow[t]{4}{*}{ Total } & 2 & 10 & 20 & 16 & 50 & 40 & $2^{\text {nd }}(\mathrm{OA})$ \\
\hline & 3 & 21 & 11 & 36 & 15 & 53 & $3^{\mathrm{rd}}(\mathrm{MA})$ \\
\hline & 4 & 18 & 20 & 76 & 8 & 14 & $4^{\text {th }}(\mathrm{CA})$ \\
\hline & 5 & 85 & 17 & 4 & 12 & 18 & $5^{\text {th }}(\mathrm{EC})$ \\
\hline
\end{tabular}

Key: $\mathrm{OA}=$ Oxythenanthera abyssinica, $\mathrm{EC}=$ Eucalyptus camaldulensis, $\mathrm{MI}=$ Mangifera indica $\mathrm{MA}=$ Melia azedirachta L., CA= Cordia africana

3.1.2. Evaluation of the Relationship between household incomes from annual low land bamboo and socioeconomic characteristics.

Linear regression model was used to see the effects of a number of socio-economic and bio-physical variables on lowland bamboo income generated per households. Among the characteristics considered land holding size was positively and highly significantly related to income generated by households $(p<0.01)$. Education level and family size was also positively and significantly related to income generated by households $(P<0.05)$. On the other hand, Household's head age, was not significantly related to households' bamboo income (Table 3.2). this result is agreed with Plirez et al.,(1999) reported that the significance of bamboo's contribution to household income can be derived from the elasticity of bamboo land and family size has a positive impact on total household income.

Table 3.2. Regression analysis of the relationship between household incomes from annual low land bamboo and socioeconomic characteristics

\begin{tabular}{|c|c|c|c|c|c|}
\hline \multirow{3}{*}{ socioeconomic characteristics } & \multicolumn{3}{|c|}{ Coefficients } & \multirow{3}{*}{$\mathrm{t}$} & \multirow{3}{*}{ Sig. } \\
\hline & \multicolumn{2}{|c|}{ Un-standardized Coefficients } & $\begin{array}{l}\text { Standardized } \\
\text { Coefficients }\end{array}$ & & \\
\hline & $\mathrm{B}$ & Std. Error & Beta & & \\
\hline (Constant) & -1001.049 & 139.665 & & -7.167 & 0.000 \\
\hline Age & 2.664 & 2.405 & 0.047 & 1.108 & 0.270 \\
\hline Education level & 61.215 & 29.072 & 0.093 & 2.106 & $0.037 *$ \\
\hline Land holding size & 838.127 & 53.650 & 0.784 & 15.622 & $0.001 * *$ \\
\hline Family size & 23.180 & 9.742 & 0.115 & 2.379 & $0.019 *$ \\
\hline
\end{tabular}

$* P<0.05, * * P<0.01, \mathrm{n}=136$

\section{CONCLUSIONS AND RECOMMENDATIONS}

\subsection{Conclusions}

Bamboo can play a crucial role in rural economy and environmental protection to sustain the livelihoods of many rural households. In study area about five tree species are dominantly used for household use to fulfill basic needs (Table 3.1). Out of the sampled households, $50 \%$ and $37.5 \%$ of the respondents ranked Mangifera indica and Lowland bamboo (Oxythenanthera abyssinica) first and second, respectively while Melia azedirachta L. and Cordia africana were preferred third (8.1\%) and fourth $(2.9 \%)$, respectively (Table 3.3. ). The majority of the respondent's ranked bamboo second next to Mangifera indica from any other trees (Table 3.1.). Among the characteristics considered land holding size was positively and highly significantly related to income generated by households $(p<0.01)$. Education level and family size was also positively and significantly related to income generated by households $(P<0.05)$. 


\subsection{Recommendation}

Among many issues come across, it is suggested that the following are important areas that deserves future research and major areas of intervention. In order to regenerate the bamboo forest there should protected from any disturbance from fire, free grazing. For this government and NGOs should play great role in order to support and create awareness to local people in the study area. Even the bamboo in natural forest is now affected by fire and free grazing and this should be controlled to provide better products with in short period of time.

The contribution of lowland bamboo to the household income is often unseen in various economic and environmental conservation surveys. Therefore, it is recommended that policies and strategies that improve the welfare of rural people especially the poor and the land less HHs and use of bamboo for natural resource conservation should be given attention. Additionally, government and NGOs should support and encourage lowland bamboo and lowland bamboo based activities as part of the diversified livelihood strategies. There should also need further research regarding to marketing system and creating marketing chain for farther implementation of bamboo cultivation.

\section{REFERENCE}

1. ECOMAR Consult.(2011). Community Based Bamboo Development in Nensebo-Kokosa Areas. Afforestation and Reforestation of Degraded Grazing Land for Carbon Sequestration Feasibility Study, Ethiopia, Addis Ababa.61 pp.

2. Ensermu Kelbessa, Tamrat Bekele, Alemayehu Gebrehiowt, Gebremedhin Hadere, (2000). The SocioEconomic Case Study of the Bamboo Sector in Ethiopia: An Analysis of the Production-to-consumption system, Ethiopia. pp 55

3. FAO. (2007). World Bamboo Resources :A Thematic Study Prepared in the Framework of the Global Forest Resources Asses sment 2005.Rme, Italiy, Rome, 73p.

4. INBAR. (2011). The Value Chain Development and Sustainability of Bamboo Housing in Ethiopia. Beijing, China, 129p.

5. Kassahun Embaye, (2003). Ecological Aspects and Resource Management of Bamboo Forests in Ethiopia, Doctoral thesis, Swedish University of Agricultural Sciences, Uppsala.Pp.40-60.

6. Kassahun Embaye. (2000). The indigenous Bamboo forests of Ethiopia: an overview. Ambio Royal Swedish Academy of Sciences. 29 (8).

7. Kumar A. and C.B Sastry .(1999). Non wood forest products and income generation. Unasylva.198:50.71Pp.

8. LUSO Consult, (1997). Study on Sustainable Bamboo Management (final Draft), Commissioned by GTZ, Addis Ababa, Ethiopia.

9. Nath, V., Rajat, S. P. \& Banerjee, S. K. (2009). Bamboo: its distribution, production, habitat and agroforestry . Indian forester 134, $387-396$.

10. Nath s., Rameswar D., Rabish C. and Animesh S. (2009). Bamboo based agroforestry for marginal lands with special reference to productivity, market trend and economy, jharkhand. pp 26

11. Seyoum Kelemwork. (2008). Anatomical Characteristics of Ethiopian Lowland bamboo (Oxytenanthera abyssinia).presentation of the International Network for Bamboo and Rattan (INBAR). January 16, 2008. Beijing, China.

12. Tesfaye Hunde.(1998). Status of Bamboo Resources in Ethiopia paper presented at INBAR-Africa regional consultation (August 30-sep.2)

13. Tesfaye Hunde.(2007).Training of Trainers on Bamboo Cultivation and Stand management Presentation (EARIO) sponsored EABP, December 17-19, 2007.Addis Ababa, Ethiopia. pp. 1-67.

14. Yeshambel Mekuriaw, Mengistu Urge and Getachew Animut. (2011). Role of indigenous Bamboo species (Yushania alpina and Oxytenanthera abysinica) as ruminant feed in northwestern Ethiopia, department of animal production and technology, Bahir Dar University, Bahir Dar, Ethiopia. Pp18 